\title{
The effects of website quality on customer satisfaction and loyalty to online travel agencies in Vietnam
}

\author{
Nguyen Tran Nguyen Khai ${ }^{*}$, Nguyen Thi Xuan Van ${ }^{1}$ \\ ${ }^{1}$ Ho Chi Minh City International University, Vietnam National University HCMC, \\ Vietnam \\ *Corresponding author: khainguyenminh@gmail.com
}

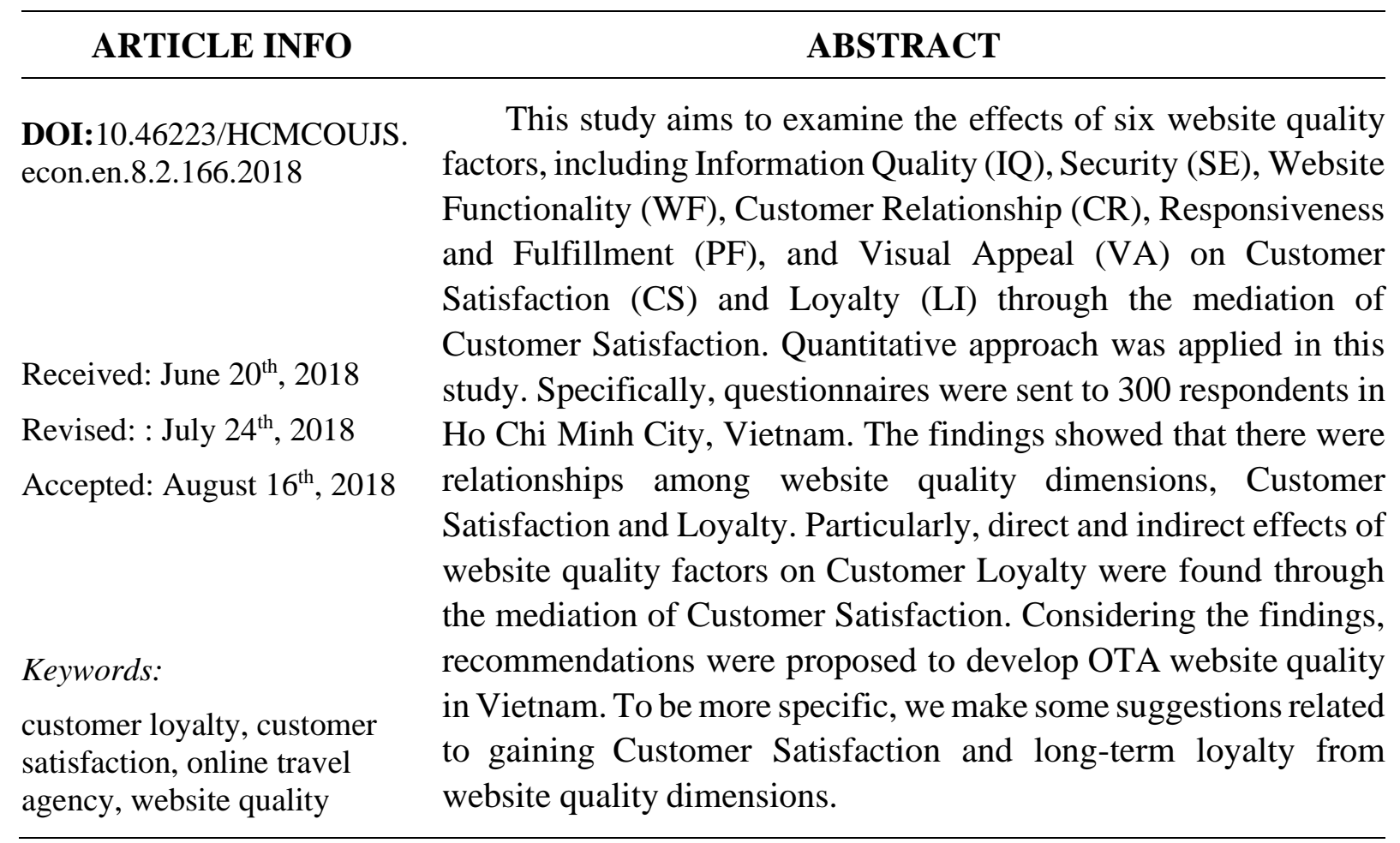

\section{Introduction}

Travel and Tourism industry has been increasing its contribution to Vietnam GDP in the last 10 years, and this proportion is expected to grow by $6 \%$ in the next decade (Turner \& Freiermuth, 2017). In recent years, there has been a huge transformation from traditional reservation channels to online channels in the hospitality industry (Kasavana \& Singh, 2001). An increase in demand for high-quality travel products and services has caused the adoption of information technologies (IT) in this field (Law, Leung, \& Wong, 2004). Specifically, a decent number of multinational hotel chains and travel agencies have used IT in their distribution, reservation, etc. (Standing, Tang-Taye, \& Boyer, 2014). Hence, the use of the Internet for services as an intermediary has been creating competitive advantages of providing travelrelated information and online transaction support (Law, Qi, \& Buhalis, 2010; Ting, Wang, Bau, \& Chiang, 2013).

Online booking is currently accounting for a large proportion of the total travel sales, according to Statistic Brain. (2017), online reservations accounted for 57\% of all the reservations made in the year 2017. In Vietnam, the revenue of OTA is predicted to grow thrice 
within 10 years (2015 to 2025), it is one of the growing fastest in Asia (Dang, 2017). Online travel agency (OTA) which was considered as a destination via World Wide Web allows customers to search and book for travel-related products online (Clemons, Hann, \& Hitt, 1999). In other words, OTA is a website that acts as an intermediary between tourism product and service suppliers with customers.

Along with the promising rise, current OTAs are facing intense competition in Vietnam. Besides, as living standards have risen more, customers have shifted their focus from gaining satisfaction in achieving cheap prices and enjoying the experience of travel. Following this phenomenon, a good number of researchers have been focusing on identifying the factors regarding website qualities that have an influence on customers' perception of the website, especially in the hospitality industry. Particularly, website quality has been found to have a significant impact on customers' behavioral intentions (Morosan \& Jeong, 2008; Wong \& Law, 2005). There have been recent studies examining the influence of website quality on customers' intention to use and purchase on travel-related websites (Bai, Law, \& Wen, 2008; Ho \& Lee, 2007; Jeong, 2004; Park, Gretzel, \& Sirakaya-Turk, 2007). According to Bai et al. (2008), more researches are needed to figure out whether Customer Satisfaction plays a mediating role in examining the website quality and behavioral intention relationship. Furthermore, the mentioned relationship has not been statistically examined in the context of Vietnam.

Considering the mentioned reasons, this study is devoted to investigate whether dimensions of website quality, based on Ho and Lee's (2007) as well as Park et al.'s (2007) frameworks, have an influence on Vietnamese Customer Satisfaction and their Loyalty to online travel agencies in Vietnam, such as Traveloka, Agoda, iViVu, Trivago, etc. Specifically, Ho and Lee's (2007) study was dedicated to researches on online travel-related services in the context of Taiwan, and it focused on the set of measures for website quality rather than on its relations with customers' behavior intentions. As for Park et al.'s (2007) study, the study concentrated on the relationship of website quality with customers' behavioral intention in the United State, in which online travel services have been emerging and developing for a long time. From these differences, this study promises more detailed examination of the relations between the mentioned variables in Vietnam, an emergent country.

\section{Literature review}

\section{Customer Satisfaction}

In marketing, Customer Satisfaction is an important and well-studied concept (Kotler \& Armstrong, 2004). From Giese and Cote (2002), Customer Satisfaction was understood as either cognitive or affective response that exists through a certain time of the purchasing process. In other words, Customer Satisfaction is customers' evaluation of a product or service whether they are able to meet their needs and expectations or not (Oliver, 1980). To sum up, even though a decent number of studies aim to measure the construct, two ways among them were greatly appreciated to measure Customer Satisfaction as a cognitive or affective response from customers that appear at a time after the purchase of a product. Along with technological advancements, a significant number of researches were done to examine Customer Satisfaction in the online environment, which was denoted as e-satisfaction (Isfandyari-Moghaddam, 2014). E-satisfaction which is similar to the satisfaction concept was defined as the contentment customers' previous purchasing experience in an electronic company (R. E. Anderson \& Srinivasan, 2003). According to H. Kim (2005), the same concept referred to the evaluation of the prior purchase process and customers' experience of product usage experience. 
Previous researchers have found that Customer Satisfaction resulted from service quality (E. W. Anderson \& Sullivan, 1993; Oliver, 1993; Zeithmal, Bitner, \& Gremler, 2006) and could lead to Customer Loyalty (Choi \& Chu, 2001; Kandampully \& Suhartanto, 2003). In travel industry, Wen (2012) made an attempt to measure customers' satisfaction and found that this construct is related to customers' purchase experience. Furthermore, satisfied consumers tend to be highly motivated to purchase and recommend the company to others more frequently (Zeithaml, Berry, \& Parasuraman, 1996). Hence, H. Kim (2005) asserted that it was vital to figure out how to measure e-satisfaction, because this construct was linked with repeat purchase intention and purchase behavior, the two variables have a significant contribution to the success of online businesses.

\section{Customer Loyalty}

Customer Loyalty was originally defined as customers' biased attitudes and behavioral responses throughout the decision process to choose a brand out of a set of brands (Jacoby \& Chestnut, 1978). Oliver (1999) also referred to this construct as customers' deep commitment to make a repurchase of a preferred product or service consistently. Besides, in his research Oliver proposed a process of customer loyalty which contains 3 steps: (1) valuing the product or service (cognitive loyalty); (2) having favorable attitudes towards the product or service (affective loyalty); and (3) possessing repeated purchase intention (cognitive loyalty). True loyal consumers are extremely valuable to businesses, since the effect of customer loyalty can affect firms' financial outcomes (Reichheld, Markey, \& Hopton, 2000). Particularly, they tend to overlook companies' flaws as well as prices and they will recommend the brand to others.

Considering the previous studies, e-loyalty is considered as the level in which customers are willing to visit online shopping websites and purchase goods or services again, as well as their intention to recommend the company to other people. Specifically, on the virtual environment, Reichheld et al. (2000) believed that e-loyalty was relatively similar to the original loyalty, and was understood as the intention to revisit and repurchase in e-stores in the future (Flavián, Guinalíu, \& Gurrea, 2006; Srinivasan, Anderson, \& Ponnavolu, 2002). Besides, in several previous studies, this concept was conceptualized as purchase intention in the online environment (R. E. Anderson \& Srinivasan, 2003; Oliver, 1999). To get a better grasp of this construct, it is vital that the antecedents and consequences of e-loyalty provide better services and keep existing customers of e-retailers (R. E. Anderson \& Srinvasan, 2003; Srininvasan, Andersons, \& Ponnavolu, 2002). Specifically, this construct was found for the outcome of e-satisfaction (Anderson \& Srinivasan, 2003; Balabanis, Reynolds, \& Simintiras, 2006; Chiou, 2004; Flavián et al., 2006), and it was significantly moderated by company level variables, such as trust and perceived value as well as individual variables (e.g., convenience motivation, purchase size, etc.) (Anderson \& Srinivasan, 2003).

\section{The Website Quality Dimensions Affect Customer Loyalty}

Website quality was considered as a complicated multi-dimensional construct (Ahn, Ryu, \& Han, 2007), and was asserted by Hsu, Chang, and Chen (2012) that hotels should understand the impact of this important factor to customers' behavior. Numerous scholars investigated different dimensions of measuring website quality. For this study, the factors were based on studies of Ho and Lee (2007), and Park et al. (2007) including six dimensions: Information quality, Security, Website functionality, Customer relationships, Responsiveness and Fulfillment, and Visual appeal. 
Information quality was defined as the accuracy and timeliness of the information that a website is able to provide to customers (Ho \& Lee, 2007). This dimension is related to the information presented on the websites and it is able to serve customers in the website usage, decision to purchase goods or services and affect their attitudes towards websites. According to Bai et al. (2008), information quality belongs to the website quality construct and it has a direct impact on customers' purchase intention and also was viewed as e- loyalty (Flavián et al., 2006; Srinivasan et al., 2002) through the mediation of customer satisfaction.

Security was defined as the level to which a website is safe and able to protect customers' personal information by Parasuraman, Zeithaml, and Malhotra (2005). To be more specific, it can be referred to as the ability to protect customers' information, site popularity, and provide clear transaction procedures on a website (Ho \& Lee, 2007). This dimension is one of the exclusive factors to qualify tourism services in the online environment, since customers who use services from traditional methods, especially from brick-and-mortar agencies, do not need to worry about security a lot. Previous studies had found that purchasing on shopping websites possesses greater uncertainty (Kwon, Kim, \& Lee, 2002); hence, security was one of the crucial antecedents of trust and satisfaction for online purchase decisions (W. G. Kim \& Kim, 2004).

Website functionality includes features regarding the ease of use, including accessibility and navigation of the website (Ho \& Lee, 2007). Website functionality appeared in a large number of previous studies in the related topic as a vital factor of e-travel service, which proved that it was the antecedent of several users' behavioral intentions and attitudes. Furthermore, website functionality was found to influence website visitors' satisfaction, and directly related to their behavioral intention in website selection (H. Kim \& Fesenmaier, 2008). In the tourism and hospitality industry, customers' revisit and purchase intentions were identified to be significantly influenced by web functionality (Jeong \& Lambert, 2001; Jeong, Oh, \& Gregoire, 2001; W. G. Kim \& Kim, 2004).

Customer relationship is a broad concept that has been with previous studies, and its components are also diversified. However, in this study, customer relationship was adopted from Ho and Lee (2007), who thought that customer relationship is related to the personalized services offered to customers and the interactions among website users in the online community. This feature was proved to promote members' identification and increase the worthiness of the community (Algesheimer, Dholakia, \& Hermann, 2005). In terms of interaction among website users, participation in the website community enables knowledge sharing, idea dissemination and emotional support among the members (Koh \& Kim, 2004). Emphasis on product or service attributes such as customer relationship was proved to effectively increase satisfaction of customer (Toufaily, Ricard, \& Perrien, 2013). In terms of customer relationships, member interaction was found to influence consumer e-satisfaction, which led to member loyalty towards the community (Pai \& Tsai, 2011). In conclusion, customer relationship appears to be the sole factor among the proposed website quality variables to directly affect the interactions of website users. Besides, this study also adapted the dimension in which customer relationship was able to show the care of websites to their users, it was relative because OTA websites are in the introduction stage in Vietnam.

Responsiveness is the capacity of a website to respond to its customers' questions, problems (Ho \& Lee, 2007) or requests, and satisfactory (Park et al., 2007). In comparison with brick-and-mortar providers, e-retailers often lacked direct and timely interaction with the 
customers (Yang \& Jun, 2002), which rendered this dimension as an important quality for online service. Practically, many companies failed to fulfill this dimension (Kaynama \& Black, 2000), even though it was recognized by consumers as a method to increase service quality (Voss, 2003). Supportively, previous researchers also identified this dimension as a common and vital criterion for customers to evaluate a web site (Long \& McMellon, 2004; Yang \& Jun, 2002; Zeithaml, Parasuraman, \& Malhotra, 2002). Meanwhile, Fulfillment was defined as the website's success in delivering products or services and the inclination to correct any fraud in the transaction process (Ho \& Lee, 2007). This dimension included the accuracy of the transaction process and how easy customers execute that procedure (Park et al., 2007). An ordering process without errors and timely delivery were being emphasized for this dimension by Wolfinbarger and Gilly (2003). Overall, responsiveness and fulfillment are considered as a dimension since they are interrelated to each other. Particularly, it is futile for customers to receive a prompt, yet unreliable reply from OTA companies and vice versa. Furthermore, order fulfillment, prompt delivery, and billing accuracy were found to be predictors of Customer Loyalty to the company (Wolfinbarger \& Gilly, 2003).

According to Park et al. (2007), the design of a website was regarded as a visual appeal. Another concept is aesthetics, which is similar to a visual appeal in website quality context, was defined as the combination of different factors to make an overall impression of visual beauty (Wang, Minor, \& Wei, 2011). Website design has an influence on the user's perception of the site (Simon, 2000), which was able to impact the visit intention of website users (Xiang \& Fesenmaier, 2005). Besides, a website with a decent visual appeal was able to increase customer's revisit intention (Park \& Gretel, 2007). To sum up, visual appeal is the first factor that customers encounter when interacting with an OTA website; hence, it is highly related to the first impression and overall attractiveness that customers perceive from the website. Hence, maintaining a high-quality website design is an important factor in customers' e-satisfaction.

\section{Methodology}

\section{Research proposed framework}

Considering the importance of website quality dimensions, this study is devoted to investigate whether dimensions of website quality, based on Ho and Lee's (2007) as well as Park et al.'s (2007) frameworks, have an influence on Vietnamese Customer Loyalty to OTAs in Vietnam. Websites

H1: Website Quality dimension has an influence on Customer Satisfaction of OTA

H2: OTA Website Quality dimensions and Customer Satisfaction have an influence on their Loyalty to OTA Websites

H3: OTA Website Quality dimensions has an influence on Loyalty through the mediation role of Customer Satisfaction

\section{Questionnaire design and data collection}

The research applied a quantitative method, which utilized the data in numbers, mathematics, statistical tools and so on, to measure the accuracy of respondents' answers. This method is specifically beneficial to measure and analyze data on the relationship between independent and dependent variables proposed in the model. 
An online survey was conducted for data collection. The respondents were selected about one month and they were people who have used OTA to book for accommodations in HCM City. Questionnaires were sent both online and offline with helpful guidance information on questionnaires. The offline method was the main means in the survey and in the online method, questionnaires were sent to the respondents by e-mails, or on Facebook fan page of travelers, etc.

The questionnaire used to collect quantitative data consists of three following parts: (1) Customers' experience and habit of using OTA websites, (2) Customers' evaluations on OTA websites. Likert scale method was applied with anchors ranging from "1 - strongly disagree" to "5 - strongly agree", (3) Demographic information and experience with OTA websites of respondents.

\section{Sample background}

From the data collection process, 300 responses were selected from Vietnamese customers who have the experience of using OTA websites to book accommodation. Particularly, the percentage of female respondents was higher than that of males, $57.33 \%$ and $42.67 \%$ respectively. Besides, the majority of respondents belonged to the $20-24$ age group with $44.60 \%$. The second group from 25 - 29 years of age with $25.82 \%$. The other two groups accounted for $15.48 \%$ and $14.08 \%$ respectively at the age of 30 and older, and at the age of 19 and younger. In terms of income, the income groups that accounted for the majority of the respondents ranged from above 1,000,000 VND to 10,000,000 VND with more than 75\% of the total. The two groups which ranged from 1,000,000 VND below to over 10,000,000 made up $13.10 \%$ and $10.71 \%$ respectively. With respect to marital status, a huge proportion of the respondents $(65.48 \%)$ was single. Besides, the number of married respondents was half the singles, with $27.38 \%$. The remaining was $7.14 \%$ for other categories, including people who were divorced, engaged, etc. For education, more than $50 \%$ of the respondents were college students. The second proportion was the group of graduated people with $32.14 \%$, followed by the category of post-graduate such as Master Degree, Doctor Degree, etc. Finally, the least part of the respondents belonged to High school or below with approximately $2.18 \%$.

In surveying the traveling and OTA using habit, Booking.com was the most used website of respondents with more than $30 \%$, followed by Traveloka with $25.93 \%$ and Agoda with $19.58 \%$. The remaining ranged from $0.53 \%$ to $7.14 \%$ of the total respondents included OTA websites such as Chudu24, Trivago, Ivivu, Mytour, Airbnb, etc. Besides, $70.24 \%$ of the respondents did not have the experience of reviewing OTA websites and the majority of the respondents, which made up nearly $60 \%$ of the total respondents, made one to six trips for the past two years.

\section{Research findings}

\section{Table 1}

Summary of independent variables with reliability coefficients

\begin{tabular}{|l|l|c|c|}
\hline \multicolumn{2}{|l|}{ Given names } & No. of items & Alpha \\
\hline Factor 1 & Information Quality (IQ) & 6 & .881 \\
\hline Factor 2 & Security (SE) & 6 & .912 \\
\hline
\end{tabular}




\begin{tabular}{|l|l|c|c|}
\hline \multicolumn{2}{|l|}{ Given names } & No. of items & Alpha \\
\hline Factor 3 & Website Functionality (WF) & 7 & .896 \\
\hline Factor 4 & Customer Relationship (CR) & 4 & .859 \\
\hline Factor 5 & Responsiveness and Fulfillment (PF) & 6 & .837 \\
\hline Factor 6 & Visual Appeal (VA) & 5 & .886 \\
\hline
\end{tabular}

Source: The researcher's data analysis

\section{Table 2}

Summary of dependent variables with reliability coefficients

\begin{tabular}{|l|l|c|c|}
\hline \multicolumn{2}{|l|}{ Given names } & No. of items & Alpha \\
\hline Factor 7 & Customer Satisfaction (CS) & 6 & .934 \\
\hline Factor 8 & Customer Loyalty (LI) & 5 & .919 \\
\hline
\end{tabular}

Source: The researcher's data analysis

\section{Factor Analysis and Reliability}

In this analysis, Reliability Test (Cronbach's Alpha) and Exploratory Factor analysis (EFA) were tested on the Independent Variables and Dependent Variables.

Regarding independent variables, KMO value was .850 and Barlett's test of Sphericity value was significant $(\mathrm{p}=.000)$, which proved that this factor analysis was valid. Besides, the six variables made up for 67.003 percent of the total variance, which was higher than 50 percent.

For dependent variables, KMO value was .939, which was higher than .6. Besides, Barlett's test of Sphericity had a significant level of $p=.000$. Hence, two dependent variables were reasonable in terms of statistics. Furthermore, these two variables accounted for 75.817 percent of the total variance.

\section{Factors Affecting LI}

In Pearson's Correlation Analysis, the strength of linear connections between independent variables with each other and with dependent variables was calculated. All factors were correlated with each other. The highest correlation was between CS and LI, indicating that Customer Satisfaction was closely related to their loyalty to an OTA website. Other independent variables were correlated with LI at .160, .196, .235, .262, .243, and .059 for IQ, SE, WF, CR, PF, and VA respectively. From Multiple Regression Analysis, it can be concluded that CS and CR were the two factors that had direct significant positive effects on Customer Loyalty with $\mathrm{B}=.699$ and $\mathrm{B}=.134$ respectively. It inferred that the higher the customer relationship and satisfaction dimension of the website customers perceive when using it, the higher the level of customer loyalty increases. Besides, the model summary table showed that $\mathrm{R}$ square was .483, which infers that $48.3 \%$ variation of Customer Loyalty to OTA websites was explained by the model. 


\section{Indirect effects}

Particularly in this model, CS is the moderating factor that directly affects LI and it is also affected by six independent variables. Hence, the variables that directly influenced CS also had an indirect effect on LI. In this case, IQ, SE, WF, CR and PF were factors affecting CS; and therefore, the indirect effects of these variables on LI through the mediation role of CS were calculated according to Path analysis. Specifically, the results were at (.135), (.085), (.159), (.074) and (.139) for five independent factors IQ, SE, WF, CR and PF respectively.

\section{Significance of the Indirect Effects}

Bootstrapping method was conducted through Preacher and Hayes (2008) to verify the significance of the calculated indirect effects. According to Preacher and Hayes (2008), if there was a zero between lower (LLCI) and upper (ULCI) boundary of the confidence interval, the indirect effect was not significant; otherwise, it could be confirmed. Table 3 shows the result of bootstrapping test on this model. In this case, all of the indirect effects of IQ, SE, WF, CR, and PF on LI through the mediating role of CS were verified at $90 \%$ confidence interval, since the LLCI and ULCI were positive and no zero lies between them. The mentioned effects were at $\mathrm{B}=.135, \mathrm{~B}=.085, \mathrm{~B}=.159, \mathrm{~B}=.208$, and $\mathrm{B}=.139$ respectively.

\section{Table 3}

Effect coefficients between independent variables, CS and LI

\begin{tabular}{|l|c|c|c|c|c|}
\hline \multirow{2}{*}{ Variables } & \multicolumn{3}{|c|}{ Causal Effects } & \multirow{2}{*}{ LLCI } & \multirow{2}{*}{ ULCI } \\
\cline { 2 - 4 } & Direct & Indirect & Total & & \\
\hline CS & .699 & --- & .699 & & .1983 \\
\hline SE & --- & .135 & .135 & .0775 & .1476 \\
\hline WF & --- & .085 & .085 & .0293 & .2437 \\
\hline CR & --- & .159 & .159 & .0873 & .1502 \\
\hline PF & .134 & .074 & .208 & .0083 & .2207 \\
\hline VA & --- & .139 & .139 & .0636 & \\
\hline Total & --- & --- & --- & & \\
\hline
\end{tabular}

Source: The researcher's data analysis

\section{The causal Effects of Tourists' Loyalty}

From Table 3, it can be seen that CS factor possessed the strongest influence on Customer Loyalty with $\mathrm{B}=.699$, followed by Customer Relationship $(\mathrm{B}=.208)$, WebsiteFunctionality $(\mathrm{B}=.159)$, Responsiveness and Fulfillment $(\mathrm{B}=.139)$, Information Quality $(\mathrm{B}=.135)$, and Security $(\mathrm{B}=.085)$. Overall, the total effects of these variables on Customer Loyalty are 726. 


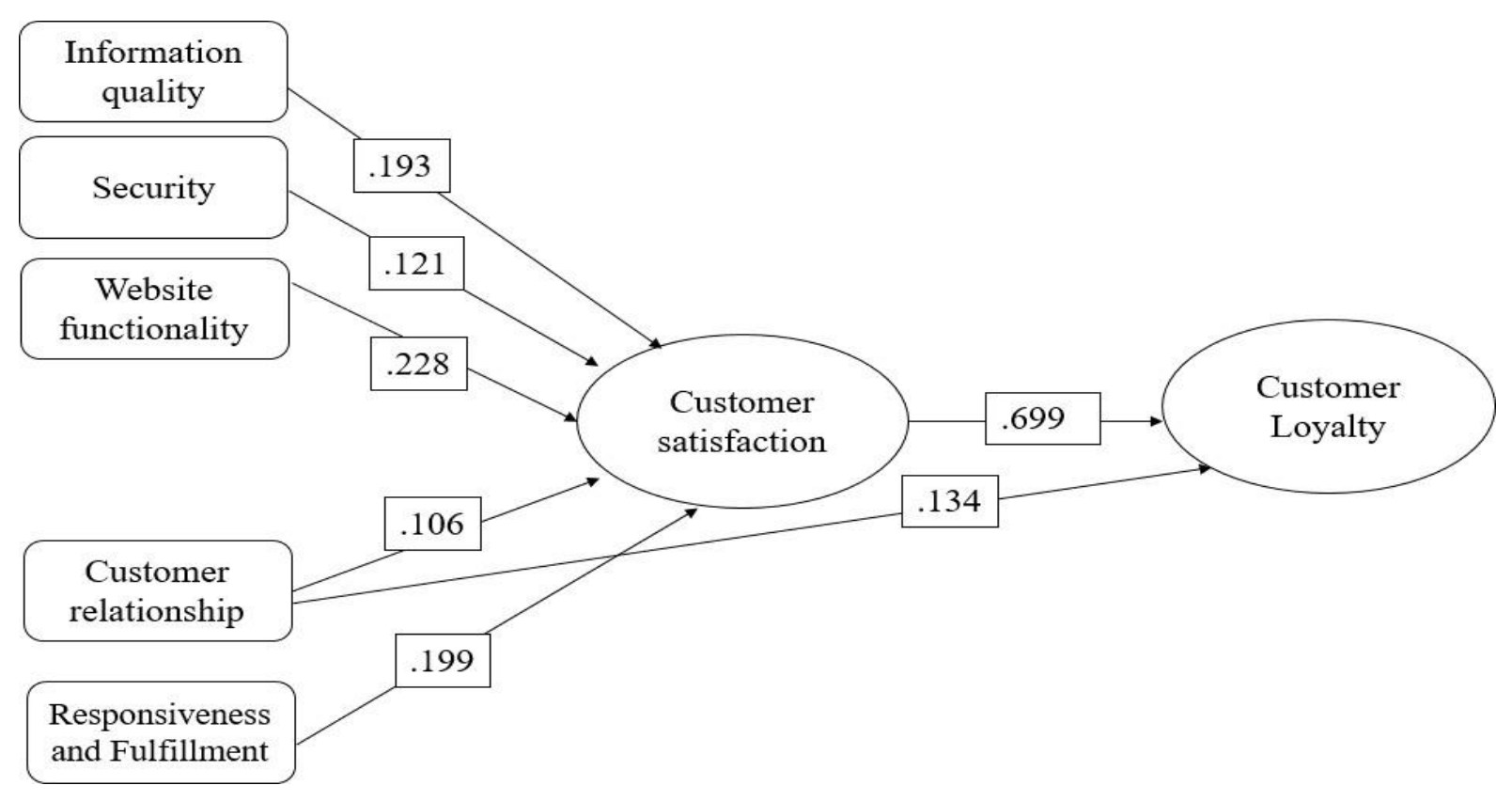

Figure 1. Path coefficients of hypothesis testing

\section{Discussion and recommendation}

\section{Discussion}

The link of website quality to Customer Loyalty was found to be relatively strong in the study. Specifically, two factors, CS and CR, had a significant effect on LI at B =.699, Sig = .000 ; and $\mathrm{B}=.134$, Sig $=.004$. Besides, five factors, including IQ, SE, WF, CR and PF indirectly affected the loyalty variable through the mediating role of Customer Satisfaction, which suggested the fact that OTA website quality may guarantee customers' loyalty to the website. From path analysis, the total effects of IQ, SE, WF, CR and PF on LI were (.135), (.085), (.159), (.208), and (.139) respectively. In terms of the relationship between Customer Satisfaction and Loyalty, a great number of previous researches also asserted the same ideas. Specifically, the degree of satisfaction was the antecedent of Customer Loyalty (Kandampully \& Suhartanto, 2003). Additionally, satisfied customers had the tendency to recommend the company to others more frequently, which was an act of customer loyalty (Zeithaml et al., 1996). Supportively, Customer Satisfaction was the main determination of customers' behavioral intention (Liao, Chen, \& Yen, 2007).

With respect to the relationship of independent variables for Customer Loyalty, several studies have the same findings. According to Ho and Lee (2007), e-service quality, including website functionality, responsiveness and fulfillment, customer relationships, information quality and security, subsequently affected Customer Loyalty. The mediating role of Customer Satisfaction was also highlighted in the link between website quality and behavioral intention in previous researches. It was found that E-service quality had a strong influence on customer e- satisfaction, and then to e-loyalty (Yen \& Lu, 2008). Supportively, Dabholkar, Shepherd, and Thorpe (2000) proposed that customers formed an effective evaluation known as satisfaction based on their attitudes towards the performance of the products, then it, in turn, led to their loyalty.

In this study, Visual Appeal (VA) of the OTA website did not significantly affect 
Customer Satisfaction either. The reason may be due to the fact that nowadays the website of good quality leads customers to consider this dimension as a hygiene factor or, conversely, it only affects customers' behavioral intention negatively when it is of extremely poor quality. Besides, most of the OTAs nowadays follow a general trend of minimalism so their websites look similar in appearance.

Furthermore, the findings were aligned with previous researches regarding user experience (UX), which was a kind of experience customers perceive from the use of service functionality (Väänänen-Vainio-Mattila, Wäljas, Ojala, \& Segerståhl, 2010), and user interface (UI) which was basically the website design in the case. Regarding UX design, investing in this aspect, namely improving usability, ease of use, and functions related to the interaction between customers and products, is able to increase customer satisfaction and loyalty (Kujala, Roto, Väänänen-Vainio-Mattila, Karapanos, \& Sinneläa, 2011). As for UI, according to Hackos and Redish (1998), users unconsciously acknowledged the design; and therefore, perceive it has no effect on their behaviors.

\section{Recommendations}

Considering the results from this study, OTA website developers and managers should pay attention to enhance the five independent variables of website quality (Information Quality, Security, Website Functionality, Customer Relationship, Responsiveness and Fulfillment), since those aspects have positively affected Customer Satisfaction and loyalty to the site.

Customer Relationship (CR), which includes user online communication as well as interactions between the organizations with customers through OTA websites. Even though this dimension does not have as a strong effect on Customer Satisfaction as other dimensions, it possesses the highest significant effect on Customer Loyalty. This implies the fact that this dimension should be one of the first factors developed as an effective tool to increase Customer Satisfaction and then to Customer Loyalty. First of all, the items belong to this dimension that are CR4 and PF7 have the highest means of 3.49 and 3.48, and they are mainly about the site with the platform for comments and reviews. Hence, these channels should be invested and taken care of more than others in the OTA websites. Secondly, websites should make customers feel more convenient and cared about using websites. For example, OTA website should be developed to memorize customer online behavior, such as tracking cookies so that OTA companies can display an advertisement or send electronic e-mails and notifications to the appropriate market segments. These notifications can be hotel newsletters, catalogs, promotions, etc. When hotels have special offers on certain holidays, customers who frequently search for destinations can be identified and sent notices of the promotion. Thirdly, OTA managers and website developers should improve an advanced database that inputs customers' information, such as name, phone number, email address, etc., when making transactions. Hence, customers can make faster transactions without submitting their information many times. Last but not least, OTA websites can show personalized features to customers who can be ranked bronze, silver, diamond, etc., for different care. For instance, higher-ranked customers' payment could not be delayed from credit confirmation if they use the same credit cards.

In this study, Security (SE), which indicates the level of safety customers perceive from the website as well as the website functions related to this dimension was identified as a factor influencing Customer Satisfaction and Customer Loyalty when using OTA websites. To 
improve this dimension, firstly, OTA companies should run formal training courses for employees who are in charge of data processing. Customers have major concerns security hacker, fraud, unexpected failure system, etc. The main purpose of the training courses is to enhance data security, monitor performance, register and monitor users, maintain data integrity, detect fraud, etc. Especially, they should organize teams specializing in customers' confirmation of online payment. Because of the item related to the confirmation of online payment, namely SE4, got the highest score from respondents with mean of 3.62. Finally, the second and third highest scored items, SE5 and SE6 with mean of 3.41 and 3.42 respectively, were about customers' perceived security; therefore, managers should also pay attention to develop attributes that assure customers of the website's safety. For instance, signs on the website indicate the trustworthiness of the website, such as " $100 \%$ reimburse", "registered with the Ministry of Industry and Commerce", etc., or showing notification of tracking cookies before using the website.

As information makes up a major contribution to website quality, it possesses an influence on Customer Satisfaction and then indirectly on Customer Loyalty, Information Quality (IQ) can be developed by OTA companies in Vietnam with the following solutions. One of the methods is to provide accurate and in-depth information about the products since the highest scored item of IQ1 with mean of 3.71 was related to hotel information. Specifically, OTA companies should collect, code, store, synthesize information in such a mean that they can provide short and brief information to customers for booking accommodations, the buyer decision process for new products or services. Especially, the information system should update information every day so they could recognize new trends, new changes in consumer demand to meet customers' needs and wants and establish distinctive competencies in the area. Since the items related to information on assisting purchasing are also scored highly such as IQ2 (mean of 3.69), IQ4 (mean of 3.66) and IQ5 (mean of 3.64). Frequent surveys should be made to study and realize customers' insight into their requirements about destinations, accommodations and their purposes. For instance, tourists travel to Can Tho or HCM City, they always ask for the locations of hotels so the information is provided to prioritize their needs.

Considering the result drawn from this study, Responsiveness and Fulfillment (PF) is considered as the factor to which has the second-highest influencing on Customer Satisfaction and the third-highest on Customer Loyalty. To increase the capacity of this dimension, firstly, a huge budget should be invested in the customer support department of assisting customers' problems immediately during working hours, since the item of quick help on the OTA website (PF5) in the study was the highest with mean of 3.75. Specifically, the company should cater to registering and paying for licenses of software that possess quick processor and automation. Since these types of software highly influence the speed of interacting with customers, they have been installed to boost the efficiency of OTA sites tremendously. In addition, a logical working process for the customer care team should be thoroughly designed by the managers in order to optimize the time and quality of back- end customer services to users. Besides, testers can do their work daily or weekly to keep records of the time spent on customer support. Secondly, OTA companies should pay attention to optimize website interface in order to increase convenience when customers seek help on OTA sites. For example, message boxes may be developed and made visible on the OTA website for visitors to notice easily. Finally, order cancellation and policies regarding booking process should be user- friendly and clearly explained to customers to understand. This was due to the fact that the item related to userfriendly canceling orders policies (PF1) has the second-highest with mean of 3.70. 
Website Functionality (WF) is considered as one of the top influential factors of website quality on Customer Satisfaction and Customer Loyalty when using OTA websites in this study. Hence, OTA companies should allocate a high proportion of resources to improve this dimension of their websites. Specifically, OTA companies' managers should improve operational efficiency, which is closely linked to website functionality. First and foremost, in this study, the second most valued item in this factor was WF2 (mean equals 3.78), represents the convenient and fast usage of website, and it can be improved designing the website with convenient link and fast connections. Specifically, hyperlinks of OTA websites may be made short and easy to remember. Besides, bandwidth and hosting should be chosen to maximize the access speed to the sites. Secondly, increasing ease of use of OTA websites is also an approach to develop this dimension. Efforts should be made to increase the usefulness; for instance, repeated information can be shown on the home page with links. Thirdly, search function should be optimized, as helpful search function (WF6) was the second-highest with mean of 3.78 in WF. Specifically, an optimized search function minimizes the time customers spent on finding needed products on the websites, it is also an approach in fastening the overall processing speed of the page by designing the search algorithm. Particularly, orders of hotels should be flexible depending on customers' purposes of traveling, customers' preference from tracking their cookies, etc. Additionally, other functions advocating booking transactions should be incorporated on the websites, because quick transactions also increase the operational efficiency of the sites. In addition, as the highest scored item of this factor is related to website functions to assist customers in saving their time, which was WF1 with mean of 3.81, website developers should also arrange information and categories logically on the sites.

\section{Conclusion}

This study was able to achieve the goals and answer the three research questions proposed in Chapter 1. Specifically, six factors belong to website quality namely Information Quality, Security, Website Functionality, Customer Relationship, Responsiveness and Fulfillment, and Visual Appeal were examined in the relationship with customer relationship and loyalty. The research was able to understand the factors affecting customers' attitude towards the website, as well as their intention to revisit and recommend to other people.

The study found significant relations among the proposed variables from 300 respondents collected from the questionnaire survey. Besides, the supported hypotheses were sufficient to verify the direct and indirect effects of website quality dimensions (IQ, SE, WF, CR, PF, and VA) on Customer Loyalty mediated by Customer Satisfaction. Among the independent variables, Customer Relationship was the only factor that has both direct and indirect influences on Customer Loyalty. Other factors besides Visual Appeal showed significant effects on Customer Satisfaction, and indirect effects on Customer Loyalty through the mediation of Customer Satisfaction. Besides, it is found that Customer Relationship possesses the highest total effect on Customer Loyalty with $\mathrm{B}=.208$, followed by Website Functionality ( $\mathrm{B}=.159)$, Responsiveness and Fulfillment $(\mathrm{B}=.139)$, Information Quality $(\mathrm{B}=$ $.135)$, and Security $(\mathrm{B}=.085)$ respectively.

From these findings, certain solutions to the current problems of the tourism industry can be proposed regarding developing OTA websites to improve Customer Satisfaction and Loyalty. 


\section{References}

Ahn, T., Ryu, S., \& Han, I. (2007). The impact of Web quality and playfulness on user acceptance of online retailing. Information \& Management, 44, 263-275. doi:10.1016/J.IM.2006.12.008

Algesheimer, R., Dholakia, U. M., \& Hermann, A. (2005). The social influence of brand communities: Evidence from European car clubs. Journal of Marketing, 69(3), 19-34. doi:10.1509/jmkg.69.3.19.66363

Anderson, E. W., \& Sullivan, M. W. (1993). The antecedents and consequences of customer satisfaction. Marketing Science, 12(2), 125-143. doi:10.1287/mksc.12.2.125

Anderson, R. E., \& Srinivasan, S. S. (2003). E-satisfaction and e-loyalty: A contingency framework. Psychology \& Marketing, 20(2), 123-138. doi:10.1002/mar.10063

Bai, B., Law, R., \& Wen, I. (2008). The impact of website quality on customer satisfaction and purchase intentions: Evidence from Chinese online visitors. International Journal of Hospitality Management, 27(3), 391-402. doi:10.1016/j.ijhm.2007.10.008

Balabanis, G., Reynolds, N., \& Simintiras, A. (2006). Bases of e-store loyalty: Perceived switching barriers and satisfaction. Journal of Business Research, 59(2), 214-224. doi:10.1016/j.jbusres.2005.06.001

Chiou, J. S. (2004). The antecedents of consumers' loyalty toward Internet service providers. Information \& Management, 41(6), 685-695. doi:10.1016/j.im.2003.08.006

Choi, T. Y., \& Chu, R. (2001). Determinants of hotel guests' satisfaction and repeat patronage in Hong Kong hotel industry. International Journal of Hospitality Management, 20(2), 277-297. doi:10.1016/S0278-4319(01)00006-8

Clemons, E. K., Hann, I.-h., \& Hitt, L. M. (1999). The nature of competition in electronic markets: An empirical investigation of online travel agent offerings (Department of Operations and Information Management Working Paper, The Wharton School). Retrieved January 10, 2018, from http://citeseerx.ist.psu.edu/viewdoc/summary?doi=10.1.1.39.2859\&rank=1

Dabholkar, P. A., Shepherd, C. D., \& Thorpe, D. I. (2000). A comprehensive framework for service quality: An investigation of critical conceptual and measurement issues through a longitudinal study. Journal of Retailing, 76(2), 139-173. doi:10.1016/S00224359(00)00029-4

Dang, H. (2017, October). OTA Việt trước áp lục tự đổi móit. [OTA Viet facing the reformation pressure]. Retrieved January 9, 2018, from http://tiasang.com.vn/-doi-moi-sangtao/OTA-Viet-truoc-ap-luc-tu-doi-moi 10980

Flavián, C., Guinalíu, M., \& Gurrea, R. (2006). The role played by perceived usability, satisfaction and consumer trust on website loyalty. Information \& Management, 43(1), 114. doi:10.1016/j.im.2005.01.002

Giese, J. L., \& Cote, J. A. (2000). Defining customer satisfaction. Academy of Marketing Science Review, 1(1), 1-24.

Hackos, J. T., \& Redish, J. C. (1998). User and task analysis for interface design. Hoboken, NJ: John Wiley \& Sons, Inc. 
Ho, C. I., \& Lee, Y.-L. (2007). The development of an e-travel service quality scale. Tourism Management, 28(6), 1434-1449. doi:10.1016/j.tourman.2006.12.002

Hsu, C. L., Chang, K. C., \& Chen, M. C. (2012). The impact of website quality on customer satisfaction and purchase intention: Perceived playfulness and perceived flow as mediators. Information Systems and E-Business Management, 10(4), 549-570. doi:10.1007/s10257-011-0181-5

Isfandyari-Moghaddam, A. (2014). Customer-centric marketing strategies: Tools for building organizational performance. Journal of Consumer Marketing, 31(1), 85-86. doi:10.1108/JCM-08-2013-0682

Jacoby, J., \& Chestnut, R. W. (1978). Brand loyalty: Measurement and management. New York, NY: John Wiley \& Sons Incorporated.

Jeong, M. (2004). An exploratory study of perceived importance of web site characteristics: The case of the bed and breakfast industry. Journal of Hospitality \& Leisure Marketing, 11(4), 29-44. doi:10.1300/J150v11n04_03

Jeong, M., \& Lambert, C. U. (2001). Adaptation of an information quality framework to measure customers' behavioral intentions to use lodging web sites. International Journal of Hospitality Management, 20(2), 129-146. doi:10.1016/S0278-4319(00)00041-4

Jeong, M., Oh, H., \& Gregoire, M. (2001). An internet marketing strategy study for the lodging industry. Washington, DC: American Hotel \& Lodging Foundation.

Kandampully, J., \& Suhartanto, D. (2003). The role of customer satisfaction and image in gaining customer loyalty in the hotel industry. Journal of Hospitality \& Leisure Marketing, 10(1-2), 3-25. doi:10.1300/J150v10n01_02

Kasavana, M. L., \& Singh, A. J. (2001). Online auctions. Journal of Hospitality \& Leisure Marketing, 9(3-4), 127-140. doi:10.1300/J150v09n03_09

Kaynama, S. A., \& Black, C. I. (2000). A proposal to assess the service quality of online travel agencies: An exploratory study. Journal of Professional Service Marketing, 21(1), 63-88. doi:10.1300/J090v21n01_05

Kim, H. (2005). Developing an index of online customer satisfaction. Journal of Financial Services Marketing, 10(1), 49-64. doi:10.1057/palgrave.fsm.4770173

Kim, H., \& Fesenmaier, D. R. (2008). Persuasive design of destination websites: An analysis of first impression. Journal of Travel Research, 47(1), 3-13. doi:10.1177/0047287507312405

Kim, W. G., \& Kim, D. J. (2004). Factors affecting online hotel reservation intention between online and non-online customers. Hospitality Management, 23, 381-395. doi:10.1016/j.ijhm.2004.02.001

Koh, J., \& Kim, D. (2004). Knowledge sharing in virtual communities: An e-business perspective. Expert Systems with Applications, 26(2), 155-166. doi:10.1016/S09574174(03)00116-7

Kotler, P., \& Armstrong, G. (2004). Principles of marketing (10th ed.). Upper Saddle River, NJ: Prentice Hall.Kujala, S., Roto, V., Väänänen-Vainio-Mattila, K., Karapanos, E., \& 
Sinneläa, A. (2011). UX Curve: A method for evaluating long-term user experience. Interacting With Computers, 23(5), 473-483. doi:10.1016/j.intcom.2011.06.005

Kwon, O. B., Kim, C.-R., \& Lee, E. J. (2002). Impact of website information design factors on consumer ratings of web-based auction sites. Behavior \& Information Technology, 21(6), 387-402. doi:10.1080/0144929021000050256

Law, R., Leung, K., \& Wong, R. (2004). The impact of the Internet on travel agencies. International Journal of Contemporary Hospitality Management, 16(2), 100-107. doi:10.1108/09596110410519982

Law, R., Qi, S., \& Buhalis, D. (2010). Progress in tourism management: A review of website evaluation in tourism research. Tourism Management, 31(3), 297-313. doi:10.1016/j.tourman.2009.11.007

Liao, C., Chen, J. L., \& Yen, D. C. (2007). Theory of planning behavior (TPB) and customer satisfaction in the continued use of e-service: An integrated model. Computers in Human Behavior, 23(6), 2804-2822. doi:10.1016/j.chb.2006.05.006

Long, M., \& McMellon, C. (2004). Exploring the determinants of retail service quality on the Internet. Journal of Services Marketing, 18(1), 78-90. doi:10.1108/08876040410520726

Morosan, C., \& Jeong, M. (2008). Users' perceptions of two types of hotel reservation web sites. International Journal of Hospitality Management, 27(2), 284-292. doi:10.1016/j.ijhm.2007.07.023

Oliver, R. L. (1980). A cognitive model of the antecedents and consequences of satisfaction decisions. Journal of Marketing Research, 17(4), 460-469. doi:10.2307/3150499

Oliver, R. L. (1993). A conceptual model of service quality and service satisfaction: Compatible goals, different concepts. In T.A. Swartz, D.E. Bowen, \& S.W. Brown (Eds.), Advances in service marketing and management (pp. 65-85). Greenwich, CT: JAI Press.

Oliver, R. L. (1999). Whence consumer loyalty? The Journal of Marketing, 63, 33-44. doi:10.1177/00222429990634s105

Pai, P., \& Tsai, H. (2011). How virtual community participation influences consumer loyalty intentions in online shopping contexts: An investigation of mediating factors. Behavior \& Information Technology, 30(5), 603-615. doi:10.1080/0144929X.2011.553742

Parasuraman, A., Zeithaml, V., \& Malhotra, A. (2005). E-S-QUAL: A multiple-item scale for assessing electronic service quality. Journal of Service Research, 7(3), 213-233. doi:10.1177/1094670504271156

Park, Y. A., \& Gretzel, U. (2007). Success factors for destination marketing web sites: A qualitative meta-analysis. Journal of Travel Research, 46(1), 46-63. doi: $10.1177 / 0047287507302381$

Park, Y. A., Gretzel, U., \& Sirakaya-Turk, E. (2007). Measuring web site quality for online travel agencies. Journal of Travel and Tourism Marketing, 23(1), 15-30. doi:10.1300/J073v23n01_02

Preacher, K. J., \& Hayes, A. F. (2008). Asymptotic and resampling strategies for assessing and comparing indirect effects in multiple mediator models. Behavior Research Methods, 40(3), 879-891. doi:10.3758/BRM.40.3.879 
Reichheld, F. F., Markey, R. G., \& Hopton, C. (2000). E-customer loyalty - Applying the traditional rules of business for online success. European Business Journal, 12(4), 173180.

Simon, S. J. (2000). The impact of culture and gender on web sites: An empirical study. ACM SIGMIS Database: The Database for Advances in Information Systems, 32(1), 18-37. doi:10.1145/506740.506744

Srinivasan, S. S., Anderson, R., \& Ponnavolu, K. (2002). Customer loyalty in e-commerce: An exploration of its antecedents and consequences. Journal of Retailing, 78(1), 41-50. doi:10.1016/S0022-4359(01)00065-3

Standing, C., Tang-Taye, J.-P., \& Boyer, M. (2014). The impact of the Internet in travel and tourism: A research review 2001-2010. Journal of Travel \& Tourism Marketing, 31(1), 82-113. doi:10.1080/10548408.2014.861724

Statistic Brain. (2017, May). Internet travel \& hotel booking statistitcs. Retrieved May 20, 2018, from https://www.statisticbrain.com/internet-travel-hotel-booking-statistics.

Ting, P., Wang, S., Bau, D., \& Chiang, M. (2013). Website evaluation of the top 100 hotels using advanced content analysis and eMICA model. Cornell Hospitality Quarterly, 54(3), 284-293. doi:10.1177/1938965512471892

Toufaily, E., Ricard, L., \& Perrien, J. (2013). Customer loyalty to a commercial website: Descriptive meta-analysis of the empirical literature and proposal of an integrative model. Journal of Business Research, 66(9), 1436-1447. doi:10.1016/j.jbusres.2012.05.011

Turner, R., \& Freiermuth, E. (2017). Travel \& tourism world economic impact 2017. Retrieved May 20, 2018, from The World Travel \& Tourism Council website: https://www.wttc.org/-/media/files/reports/economic-impact-research/regions2017/world2017.pdf

Väänänen-Vainio-Mattila, K., Wäljas, M., Ojala, J., \& Segerståhl, K. (2010). Identifying drivers and hindrances of social user experience in web services. Paper presented at Proceedings of the SIGCHI Conference on Human Factors in Computing Systems (pp. 2499-2502). ACM.

Voss, C. (2003). Trends in the Experience and service economy - The experience profit cycle: Research Report of Center for Operations and Technology Management, London Business School. Retrieved March 10, 2018, from https://www.researchgate.net/profile/Chris_Voss/publication/242274223_Trends_in_the _Experience_and_Service_Economy_The_Experience_Profit_Cycle/links/02e7e532026 dedb147000000/Trends-in-the-Experience-and-Service-Economy-The-ExperienceProfit-Cycle.pdf

Wang, Y. J., Minor, M. S., \& Wei, J. (2011). Aesthetics and the online shopping environment: Understanding consumer responses. Journal of Retailing, 87(1), 46-58. doi:10.1016/j.jretai.2010.09.002

Wen, I. (2012). An empirical study of an online travel purchase intention model. Journal of Travel and Tourism Marketing, 29(1), 18-39. doi:10.1080/10548408.2012.638558

Wolfinbarger, M., \& Gilly, M. C. (2003). eTailQ: Dimensionalizing, measuring and predicting etail quality. Journal of Retailing, 79(3), 183-198. doi:10.1016/S0022-4359(03)00034-4 
Wong, J., \& Law, R. (2005). Analysing the intention to purchase on hotel websites: A study of travelers to Hong Kong. International Journal of Hospitality Management, 24(3), 311329. doi:10.1016/j.ijhm.2004.08.002

Xiang, Z., \& Fesenmaier, D. R. (2005). Assessing the initial step in the persuasion process: Meta tags on destination marketing websites. Information Technology \& Tourism, 8(2), 215-226. doi:10.3727/109830506778001492

Yang, Z., \& Jun, M. (2002). Consumer perception of E-service quality: From internet purchaser and non-purchaser perspectives, Journal of Business Strategies, 19(1), 19- 41.

Yen, C., \& Lu, H. (2008). Effects of e-service quality on loyalty intention: An empirical study in online auction. Managing Service Quality, 18(2), 127-146. doi:10.1108/09604520810859193

Zeithaml, V. A., Berry, L. L., \& Parasuraman, A. (1996). The behavioral consequences of service quality. The Journal of Marketing, 60(2), 31-46. doi:10.2307/1251929

Zeithaml, V. A., Bitner, M. J., \& Gremler, D. D. (2006). Service marketing: Integrating customer focus across the firm (4th ed.). Singapore: McGraw-Hill.

Zeithaml, V. A., Parasuraman, A., \& Malhotra, A. (2002). Service quality delivery through website: A critical review of extant knowledge. Journal of the Academy of Marketing Science, 30(4), 362-375. 